\title{
THE FAT EMBOLISM SYNDROME
}

\author{
Three Case Reports and Discussion of its Relevance \\ to the Battle Casualty
}

\author{
Lieutenant-Colonel T. R. AUSTIN, M.B., Ch.B., D.T.M.\&H., F.F.A.R.C.S., R.A.M.C.* \\ Military Hospital, Tidworth
}

\section{Introduction}

BATTLE casualties in Vietnam with fractured limbs frequently became markedly hypoxic without becoming cyanosed (Collins, Gordon and Hudson 1968). The mechanism of the hypoxia is fat embolisation of the lungs, the pulmonary effects of which are sometimes only recognizable through arterial blood gas studies.

Fat embolisation may present in various ways, the following cases illustrate the syndrome:

Case 1.

A 54 year old male was admitted to hospital after a road traffic accident. He had suffered a comminuted fracture of the left femur, mid-shaft compound fracture of the right tibia and fibula and sustained a fractured ankle.

There was no evidence of any chest injury and he underwent the normal resuscitative measures and subsequent anaesthesia without incident.

Thirty hours later he became distressed and breathless. Petechiae on the chest and abdomen were noted. Blood gas analysis (arterial) gave the results-

$$
\begin{array}{lll}
\mathrm{Pa}_{02}=60 & \text { Base excess }+4 \text { (mequiv/Litre) } \\
\mathrm{P}_{\mathrm{C} 02}=36 & \mathrm{pH} & 7.4
\end{array}
$$

He made a rapid and complete recovery when placed on intermittent positivepressure ventilation (I.P.P.V.) with a high inspired oxygen tension.

\section{Case 2.}

A 32 year old female suffered the following injuries in a road traffic accidentA compound fracture of the right femur, a fractured mid-shaft of the left femur, a compound fracture of the left wrist, a comminuted fracture of the mandible and extensive soft tissue injuries.

She was just conscious before anaesthesia, but never regained consciousness afterwards. The following day, whilst spontaneously breathing oxygen enriched air. arterial blood gas analysis gave the results-

$$
\begin{array}{ll}
\mathrm{Pa}_{02}=130 & \text { Base excess }-8 \text { (mequiv/Litre) } \\
\mathrm{P}_{\mathrm{C} 02}=33.5 & \mathrm{pH}
\end{array}
$$

\footnotetext{
* Now c/o Royal Army Medical College, Millbank.
} 
Later that day the $\mathrm{Pa}_{02}$ had fallen to 55 and ventilation with pure oxygen would only give a $\mathrm{Pa}_{02}$ of 90 (it should give a $\mathrm{Pa}_{02}$ of nearly 600). Evidently a large right to left shunt was present. A diagnosis of fat embolisation syndrome was soon confirmed by the appearance of petechiae over the chest and in the right fundus. Despite I.P.P.V. with high concentrations of oxygen she died.

\section{Case 3.}

A six year old boy was admitted to hospital severely injured after a road traffic accident. He had a large laceration of the liver, necessitating a thoracic approach to repair it. There were five broken ribs on the right, but at thoracotomy the lung did not appear contused. He had extensive injuries to the right femur and right elbow.

After the thoracotomy it was decided to leave him on I.P.P.V. because of the possibility of a crushed chest syndrome developing.

The following day a routine arterial sample was taken for blood gas analysis (Table I, day one). The inhaled oxygen percentage was 34 and the $\mathrm{Pa}_{02}$ was 108 , a satisfactory

Table I

Case 3. Arterial blood gas analysis results

\begin{tabular}{c|c|c|c|c}
\hline Day & $\mathbf{P}_{\mathbf{0 2}}$ & $\mathbf{P}_{\mathrm{C02}}$ & $\begin{array}{c}\text { Base excess } \\
\text { (mequiv/Litre) }\end{array}$ & $\mathrm{pH}$ \\
\hline 1 & 108 & 58 & +5.2 & 7.38 \\
2 & 50 & 34 & +7.0 & 7.53 \\
3 & 49 & 39 & +4.5 & 7.49 \\
4 & 45 & 37 & +4.0 & 7.48 \\
5 & 200 & 36 & +3.0 & 7.50 \\
6 & 300 & 33 & +2.0 & 7.44 \\
7 & 79 & 22 & +1.0 & \\
8 & 90 & 36 & & \\
\hline
\end{tabular}

state of affairs. The $\mathrm{P}_{\mathrm{C02}}$ of 58 indicated under ventilation and this was corrected.

On day two, despite the patient's normal colour the $\mathrm{Pa}_{02}$ had declined to 50 and it stayed about this figure on days three and four, even though the inspired oxygen percentage was put up to 70 . On day five, $\mathrm{Pa}_{02}$ recovered to 200 and the next day to 300. On day six he was ventilated with air only and his $\mathbf{P a}_{02}$ was 79 . The theoretical limit for the Jackson-Rees naso-tracheal tube was being reached, so he was extubated, and the following day (eight) his $\mathrm{Pa}_{02}$ was 90 , breathing room air spontaneously.

It could be argued that the above blood gas changes could have been the result of the chest injury, but against this is that the lung looked normal at thoractomy and that such a large oxygenation defect points to a more widespread lesion than a localised area of contusion.

\section{Discussion}

In the fat embolisation syndrome there is defective oxygenation of the blood often without cyanosis. 
This paradox can be resolved by consulting the dissociation curve for oxygen in blood, that is, the relationship between oxygen tension and saturation, for at $\mathrm{a} \mathrm{Pa}_{02}$ of 50 and a $\mathrm{P}_{\mathrm{CO} 2}$ of 40 , the blood is still eighty per cent saturated. As hyperventilation is almost invariably present, the curve will be even more shifted to the left due to the effect of the lowered $\mathrm{P}_{\mathrm{CO} 2}$, so it will be more than eighty per cent saturated.

Now, it is generally accepted that at least 5 grams of reduced haemoglobin per $100 \mathrm{ml}$ of blood must be present to give visible cyanosis.

A patient who has recently been the subject of severe trauma is unlikely to have a haemoglobin of 100 per cent and if 80 per cent of what is left reaches the capillaries oxygenated, the absolute level of $5 \mathrm{~g} / 100 \mathrm{ml}$ of reduced haemoglobin needed for cyanosis may not be reached.

This brings us to the question which might well be put: if the patient is not cyanosed why is he in danger?

Richards pointed out in 1943 and more recently Freeman and Nunn (1963) have emphasised the importance of oxygen availability:

$$
\begin{aligned}
& \text { Available } \mathrm{O}_{2}=\text { Cardiac output } \mathrm{x} \text { haemoglobin concentration } \\
& \text { x } 1.34 \text { x per centage saturation }
\end{aligned}
$$

As pointed out above the haemoglobin concentration is usually diminished, as is the saturation. The only compensation open is for cardiac output to increase, and this it does in some patients enormously. Ashbough and Petty (1966) reported a patient in whom it increased to 30 litres/minute. This tremendous increase in cardiac output is accompanied by a vastly increased need of the myocardium for oxygen which may not be fully met. The greatly increased cardiac output has also a bearing on the question of cyanosis, for it would tend to prevent its appearance.

\section{Conclusion}

The fat embolisation syndrome has been described by many authors and nearly one hundred years have passed since it was first recognized. Ross, in a lecture at the Royal College of Surgeons (1969) described forty-one cases collected from accident centres all over England, and this lecture is well worth reading and re-reading.

Two of the first and classical features of the syndrome coming on after a frequently symptom free period are apprehension and restlessness, which precludes the use of a syrette of morphine in a battle situation as it will augment the underlying hypoxia.

The facilities for blood gas analysis must be immediately available for diagnosis and management.

The basis of treatment is intermittent positive pressure ventilation with sufficient concentration of oxygen to keep the $\mathrm{Pa}_{02}$ as near normal as possible.

The author believes blood gas analysis facilities and ventilators must be available as far forward as possible in a battle situation.

\section{Acknowledgements}

The author gratefully acknowledges the permission of the Consultant Surgeons, Cambridge Military Hospital, Aldershot, and the Military Hospital, Tidworth, Hants, to publish details of these cases, who were primarily under their care. 
The blood gas studies in Case 3 were performed by the staff of the Biochemistry Department, Salisbury Infirmary, to whom the author is grateful for their generous help.

\section{REFERENCES}

Ashbough, D. G. and Petty, T. D. (1966). Surg. Gynec. Obstet. 123, 493.

Collins, J. A., Gordon, W. C. Jnr. and Hudson, T. L. et al (1968). Ann. Surg. 167, 511:

Fremman, J. and NunN, J. F. (1963). Clin. Sci. 24, 135.

Ross, A. P. J. (1970). Ann. roy. Coll. Surg. Engl. 46, 159.

\section{CONSULTANT EMERITUS TO THE ARMY}

\section{New Appointment for "Unsparing Service"}

In appreciation of the long and unsparing service to the Army by many distinguished civilian consultants, the Army Board have introduced a new appointment of "Consultant Emeritus to the Army ".

The following retired consultants have accepted the appointments:

Sir Arthur Porritt, Bt., G.C.M.G., K.C.V.O., C.B.E., M.Ch., M.D., F.R.C.S., Consultant Surgeon to the Army 1954-1967, Member Army Medical Advisory Board 1950-1967, Member of Waverley Committee 1953-1956; at present Governor General of New Zealand.

Sir Rowen Boland, C.B.E., M.D., F.R.C.P., D.P.H.; Consultant Physician to the Army 1945-1970; Chairman of the Army Medical Advisory Board, 1949 to date.

Sir John Bruce, C.B.E., T.D., M.D., F.R.C.S., D.P.H.; Consultant Surgeon to the Army in Scotland 1946-1970; Member of Army Medical Advisory Board, 1957 to date.

Sir Stewart Duke-Elder, G.C.V.O., F.R.S., D.Sc., M.D., F.R.C.S., F.R.C.P.; Consultant Ophthalmic Surgeon to the Army 1951-1961.

Mr. Myles Formby, C.B.E., T.D., M.B., F.R.C.S.; Consultant E.N.T. Surgeon to the Army 1946-1966.

Sir Terence Ward, C.B.E., M.R.C.P., L.R.C.P., F.D.S., R.C.S.; Consultant Dental Surgeon to the Army 1954-1971. 